\title{
What influences a tourist to return to a cultural destination?
}

\section{Laurentina Vareiro ${ }^{1}$ (D) | José Cadima Ribeiro ${ }^{2}$ (D) | Paula Cristina Remoaldo ${ }^{3}$ (D)}

\author{
${ }^{1}$ School of Management, Polytechnic Institute \\ of Cávado and Ave/UNIAG, Barcelos, Portugal \\ ${ }^{2}$ School of Economics and Management, \\ University of Minho/NIPE, Braga, Portugal \\ ${ }^{3}$ Institute of Social Sciences/Lab2PT, \\ University of Minho, Braga, Portugal

\section{Correspondence} \\ Laurentina Vareiro, School of Management, \\ Polytechnic Institute of Cávado and Ave, \\ Campus do IPCA, 4750-810 Barcelos, \\ Portugal. \\ Email: Ivareiro@ipca.pt
}

\begin{abstract}
This study investigates the likelihood of tourists to repeat a visit to a cultural destination. We use a sample of 432 tourists who had visited Guimarães, Portugal. A cluster analysis separates visitors according to their opinion of the city's attributes. Afterward, a logistic regression analyses the variables that affect the likelihood of revisiting, taking into account the three clusters obtained. Results showed that, among the total sample, global quality of the destination had the biggest influence on the tourists' decision of whether to revisit the destination, whereas the least important reason was prior visits. These influential factors varied when different cluster group compositions were considered.
\end{abstract}

\section{KEYWORDS}

cluster analysis, cultural/heritage tourism, destination's attributes, logistic regression, repeat visit, tourists' satisfaction

\section{1 | INTRODUCTION}

Satisfaction individuals withdraw from a service is related to their emotional perception about the service (Zhang, Fu, Cai, \& Lu, 2014). Thus, based on the experience a tourist has at a destination, we can assume that the more memorable and authentic the experience is the more pleased the tourist will be (Chi \& Qu, 2008; Deng \& Pierskalla, 2011; Prayag, Hosany, \& Odeh, 2013; Vanhove, 2004; Wongpan \& Khamwon, 2016; Wu \& Liu, 2017; Yoon \& Uysal, 2005). As underlined by Bosque and Martín (2008), following a few other authors, namely, Crompton (1979) and Oliver (1997), emotions do seem to play an important role in satisfaction formation.

It is quite plausible that the satisfaction the tourist gets can be expressed through future returns to the destination or, at least, through recommendations to relatives and friends who seek living a similar experience (Petrick \& Backman, 2002; Zhang et al., 2014). Indeed, the better the destination is perceived by tourists the greater the probability of being revisited or recommended to others, considering the image plays an important role in tourists' decision-making and subsequent travel behaviour (Baloglu \& McCleary, 1999; Zhang et al., 2014). Satisfaction is the visitor's overall assessment regarding the service provided compared to the service expected (Antón, Camarero, \& Laguna-García, 2017; Chen \& Chen, 2010).
Crompton (1979) proposed that individuals' psychological dimensions play a major role in a tourist's decision of whether to visit a certain site and, thus, his or her satisfaction gathered from the visit (Bosque \& Martín, 2008; Carvalho, Salazar, \& Ramos, 2015; Martin \& Bosque, 2008; Oliver, 1997; Yoon \& Uysal, 2005). That is, cognitive and affective components play an essential role in the level of satisfaction attained (Cronin, Brady, \& Hult, 2000; Oliver, 1997). Thus, managers and marketers must acquire a good knowledge of tourists' behaviour and of their overall satisfaction towards a destination in order to position and promote it (Campo-Martínez, Garau-Vadell, \& Martínez-Ruiz, 2010; Chi \& Qu, 2008; Martin \& Bosque, 2008; Moreno, Gálvez, Ortuya, \& López-Guzmán, 2016; Yoon \& Uysal, 2005).

As underlined by many authors (viz., Bigné \& Andreu, 2004; Campo-Martínez et al., 2010; Castro, Armario, \& Ruiz, 2007; Hui, Wan, \& Ho, 2007; and Lee, Petrick, \& Crompton, 2007), the composition of the travelling group may also play a role in the level of satisfaction attained and related intention regarding a repeat visit. Furthermore, within a group visiting a place, we can expect to find individuals expressing diverse levels of overall satisfaction and the desire to return to the destination (Campo-Martínez et al., 2010).

In this paper, we address the issue of return intention in an attempt to connect the revisit intention to the perceived global quality of the destination as expressed by different segments of visitors. That 
is, we will try to determine whether the influential factors varied when different cluster groups' compositions were considered.

Looking to the literature review at international level, there are not yet consistent results concerning the return intention of visitors to a destination, mainly in emerging destinations, like the one of Guimarães, which is the municipality of our research. In this regard, we believe this empirical approach can provide a valuable contribution to the literature on tourist satisfaction and return intention. This will be possible by testing the relationship between satisfaction and the perceived overall quality of the destination and its tourist attributes, and, indirectly, tourists' motivations and profile. This study also aim to contribute to the design of planning and management policies that can more effectively address the needs and wishes of target visitors, keeping in mind the main attributes of the destination.

Guimarães is a good example of a middle-sized city located in north-west Portugal, endowed with the cultural tourism segment, and has a historical centre classified by United Nations Educational, Scientific and Cultural Organization (UNESCO) as a world cultural heritage site. This city hosted one of the 2012 European Capital of Culture (2012 ECOC) events, which facilitated the enhancement of its international visibility as a heritage site. The data used in the empirical research came from a survey conducted to tourists that visited this city during 2015 and 2016, and several analytical methods to test the hypotheses under inquiry were applied.

The paper is organized as follows: after Section 1, we review the literature on tourists' satisfaction and return intention; in the next section, we present the analytical methodology used and a summary description of Guimarães. Section 4 deals with the empirical results, followed by its discussion, and the last section includes the conclusions and policy recommendations.

\section{I TOURISTS' SATISFACTION AND REPEAT VISIT INTENTION}

Satisfaction individuals withdraw from a good or a service, including tourism services, is closely related to their emotional perception towards the good or service provided (Zhang et al., 2014). The same way, satisfaction plays a critical role in the consideration of repeating the acquisition (Antón et al., 2017; Baker \& Crompton, 2000; Bigné, Sanchez, \& Sanchez, 2001; Petrick \& Backman, 2002). Of course, the products/services provided must address a particular consumers' need. A tourism destination is, in this sense, a set of services in addition to an image. In any case, places are endowed with more complexity than single products (Carvalho et al., 2015).

The complexity of destinations relates to the composite nature of the tourism product and, similarly, to its attributes (tourism attributes), which are the features of a product or service as perceived by the tourist (Carvalho et al., 2015). This way, the satisfaction derived from visiting a place keeps a close relationship with the fulfilment of its provision as it was expected by the consumer; that is, the tourist (Antón et al., 2017; Bigné, Andreu, \& Gnoth, 2005; Bosque \& Martín, 2008; Campo-Martínez et al., 2010; Oliver, 1999). Even when dealing with a repeated provision, the level of satisfaction attained just can be evaluated post-consumption and maintains temporary validity (Grönroos,
2004; Oliver, 1999; Yoon \& Uysal, 2005). Satisfaction is related not only to the pleasure of the travel experience but also to the comparison between the initial expectations of the tourist and their perceptions. Tourist will be satisfied if the perceived experience is greater than their expectations (Chiu, Zeng, \& Cheng, 2016).

In this regard, invoking a review of the literature, Campo-Martínez et al. (2010) claim that, when a tourist has already visited a destination, his perceptions towards it tend to change, specifically those regarding the risk faced, thus influencing the expectations held. Additionally, according to the empirical research performed by Campo-Martínez et al. (2010), if travellers' expectations are fulfilled, this will contribute to their level of satisfaction attained and the intention to repeat the visit.

On the issue of satisfaction, research must consider the attributes of the destination itself (Correia, Kozak, \& Ferradeira, 2013; Moreno et al., 2016), together with the quality of services and the motivation of the visitor (Chen, Lee, Chen, \& Huang, 2011). As underlined by Bosque and Martín (2008), individuals' image of a destination has three components: cognitive, affective, and holistic aspects. The perception of tourists about the different attributes and characteristics of the destination, such as attractions, infrastructure, environment, and service quality, allows to measure the cognitive image of the destination. However, more and more, the role that the feelings and emotions of the tourists towards a destination, that is, the affective dimensions of the destination image, is emphasized in the image formation (Zhang et al., 2014). So a joint cognitive-affective approach should be adopted to capture destination image in a better way (Martin \& Bosque, 2008).

Regarding destination attributes, following the work of Oliver (1993), Chi and Qu (2008) concluded that satisfaction with city's attributes has a significant and positive influence on a tourist's overall satisfaction. The researchers add, too, that satisfaction affects destination loyalty directly and positively (Chi \& Qu, 2008), a result which matches that attained by other researchers (see Bosque \& Martín, 2008; Gandhi-Arora \& Shaw, 2002). Satisfied tourists are more likely to repeat a visit and share their positive experience with relatives and friends (Bosque \& Martín, 2008; Campo-Martínez et al., 2010; Lee, Lee, \& Arcodia, 2014; Yoon \& Uysal, 2005). One way of approaching loyalty is through the return intention, together with recommendations to relatives and friends (Antón et al., 2017; Baker \& Crompton, 2000; Campo-Martínez et al., 2010; Moore, Rodger, \& Taplin, 2015).

Chi and Qu (2008) underlined that the destination image influences perceived quality and satisfaction, in addition to playing a major role in the process of choosing a site to visit. These researchers concluded that satisfaction towards a destination results from the overall experience lived (Bigné et al., 2005; Chen \& Chen, 2010; Petrick \& Backman, 2002). A destination claims a place in the market, that is, it captures a place in tourists' minds or enhances its positioning envisaging getting the full satisfaction of the tourists it attracts, which also relates to the emotions it can provide (Bigné et al., 2005; Bosque \& Martín, 2008).

Several studies cited by Chiu et al. (2016) suggest that satisfaction is a necessary step towards tourist loyalty, with the relationship between satisfaction felt and loyalty being a positive one. Therefore, the propensity to revisit a destination or recommend it increases as levels of satisfaction increase. The same conclusion was drawn by Yoon and Uysal (2005) when examining northern Cyprus 
archaeological and historical sites, and by Poria, Reichel, and Cohen (2011), who studied a UNESCO World Heritage Site in Israel.

As emphasized by Nam, Ekinci, and Whayatt (2011), loyalty and repeated visits are not the same concept; that is, tourists can be loyal to a destination and not return to it. An explanation for this can be found in the differentiation between behaviour loyalty and psychological commitment (attitudinal loyalty). According to Zhang et al. (2014), the first definition is related to the behaviours, namely, the continued patronage and the act of recommendation. The attitudinal loyalty is defined as the general attitude towards a product or service, for example, the intention to repurchase. An alternative approach results from the aggregation of the two points of view (Zhang et al., 2014).

The priory visiting experiences in terms of travel group composition also seem to affect a tourist's intention to return (CampoMartínez et al., 2010). This is consistent with the claim that, when a tourist has already visited a destination, his/her perceptions towards it tend to change.

Considering these assertions, we believe that acquiring a good knowledge of tourists' behaviour and of their overall satisfaction with a destination or of its tourism attributes is essential for managers and marketers to position and promote it. This is even more important when dealing with an emergent destination, as is the case of Guimarães, as there is a need to identify the extent to which the attributes and components of the destination are perceived.

Additionally, as the empirical literature available on the issue seems to indicate (see Campo-Martínez et al., 2010), if different travel groups gain different levels of satisfaction from visiting a destination, then the strategies developed to attract them should address each segment motivation instead of adopting standardized promotion campaigns.

Following the review of literature, the hypotheses that we decided to test were the following:

H1. Tourists with different profile perceive differently the city's attributes.

H2. The global quality perception of the destination affects positively the intention to return.

H3. The satisfaction felt with the visit affects positively the intention to return.

H4. The prior visits to the destination affect positively the intention to return.

In what regards $\mathrm{H} 2-\mathrm{H} 4$, these hypotheses will be tested taking into account the different clusters obtained, because the different visitors profile found may influence the intention to return.

\section{I METHODOLOGY AND PRESENTATION OF THE DESTINATION}

\section{1 | Data and analytical methods}

The research methodology consisted of a quantitative approach based on a self-administered survey of 432 tourists who visited Guimarães during 2015 and 2016, aiming to investigate the likelihood of tourists to repeat a visit to a cultural destination, taking into account the relationship between the destination's global quality, tourists' satisfaction, and destination loyalty. The questionnaire was applied by technicians that work at the city of Guimarães tourism office.

As previously mentioned, the empirical literature revealed that different travel groups gained different levels of satisfaction from visiting a destination (Bigné \& Andreu, 2004; Campo-Martínez et al., 2010; Castro et al., 2007; Hui et al., 2007). Considering these findings, we believe it makes sense to inquire on the satisfaction attained by visitors endowed with different profile from their visit to Guimarães.

The questionnaire was composed by the tourism services of the municipality together with the research team. Both Portuguese and English versions were available in the tourism office for visitors to complete. Although the questionnaire was self-administered, each visitor was asked to fill in it in the presence of tourism office employees who could clarify any issue raised.

The survey included a total of 22 questions, most of them categorized and closed, and three main parts. The first relates to the visit to the destination and the motivation to do so, and the second part invites tourists to express their opinion regarding the city's attributes, global quality of the destination, and the level of satisfaction they got from the visit.

Eighteen city's attributes were considered, taking into account the tangible and intangible heritage, security, and access to the city and following the main attributes of cultural destinations. A 5-point Likert scale ranging from complete disagreement (Level 1) to complete agreement (Level 5) was used for rating the attributes. These attributes were partially adapted from a previous study (Remoaldo, Ribeiro, Vareiro, \& Santos, 2014), after an in-depth interview conducted to the head of the tourism office of the city regarding the perceived tourists' attributes of the city and tourists motivations to visit it.

Additionally, the survey respondents were invited to share their intention to return or to recommend the visit to relatives and friends (the identification of having chosen the destination as a main option of their tour was also previously inquired in this section). Finally, in the third part, they were asked about their socio-demographic features (gender, age, level of education, residence, marital status, and income level).

In the analysis of data, SPSS statistical software, version 24, was used, and we have chosen to conduct one approach following four steps:

1. In the first step, a non-hierarchical cluster analysis, using the kmeans cluster algorithm for the 18 items measuring the attributes of Guimarães was performed. The socio-demographic variables were omitted from this analysis so that tourists could be grouped only by their perceptions of the city's attributes.

2. In the second step, the socio-demographic features of the visitors included in the three groups obtained in the clusters analysis were compared with assess their profile.

3. In the third step, one-way analysis of variance tests were used to identify the differences between the three clusters regarding 
satisfaction levels, global quality of Guimarães held, previous experience with the destination, and intention to return and recommend. Analyses of variance tests were applied, because the independent variable was divided into three subgroups.

4. Finally, in order to analyse the variables that affect the likelihood of a return visit, a logistic regression analysis was performed.

The use of cluster analysis in this study relies on a previous diagnosis based on the computation of the Kaiser-Meyer-Olkin statistics. The result of the test was 0.881 , which is above the recommended value, indicating that both the sample size and the number of variables were appropriate. Cox and Snell and Nagelkerke's pseudo $R^{2}$ statistics and the -2 log likelihood were used to measure the model's goodness of fit to the data.

\section{2 | Guimarães: A cultural destination}

Guimarães is a medium-sized city located in the north-west Portugal (Figure 1). It boasts a central geographical location, $50 \mathrm{~km}$ away from Oporto (the second most important city in the country and three times deemed a Best European Destination) and in close proximity to the Oporto airport, the main entrance of foreigners into northern Portugal. It is the birthplace of the first king of Portugal and is associated with the emergence of the Portuguese national identity in the 12th century. The city serves as an example of a very well-preserved historic centre, with some buildings showing the Portuguese architecture from the 15 th to 19 th centuries.
In 2015 (the last year available), 1,983 lodging beds were available in the Guimarães municipality as a whole, accounting for $54.1 \%$ of the NUTS III Ave accommodation capacity (subregion in which Guimarães is located) (I.N.E., 2016). The city received $3.7 \%$ of the guests of the NUTS II northern region in 2015.

The historical economic export basis of the municipality highlights the importance of the textile and clothing industries.

The historical centre of Guimarães was classified by UNESCO as a World Heritage Site in December 2001. That certification came after local authorities made efforts towards the restoration and preservation of the city historical centre.

Guimarães was also a host city of the 2012 ECOC. New cultural and sports facilities have been built in recent years, including the Multipurpose Hall (Pavilhão Multiusos), the Vila Flor Cultural Centre, and the Platform of Arts and Creativity. This last equipment was built for the hosting of the 2012 ECOC.

Due to the equipment built and the general dynamic acquired for hosting the 2012 European Culture Capital, the city reinforced its positioning in the cultural and urban national tourism context.

\section{4 | RESULTS}

\section{1 | Tourists' profile}

The main features of the database regarding the socio-demographic profile of the survey respondents are as follows: $52.8 \%$ were male, the majority were $26-45$ years old (50.8\%), 31.6\% had a secondary education level and $60 \%$ had a tertiary one, the majority of them

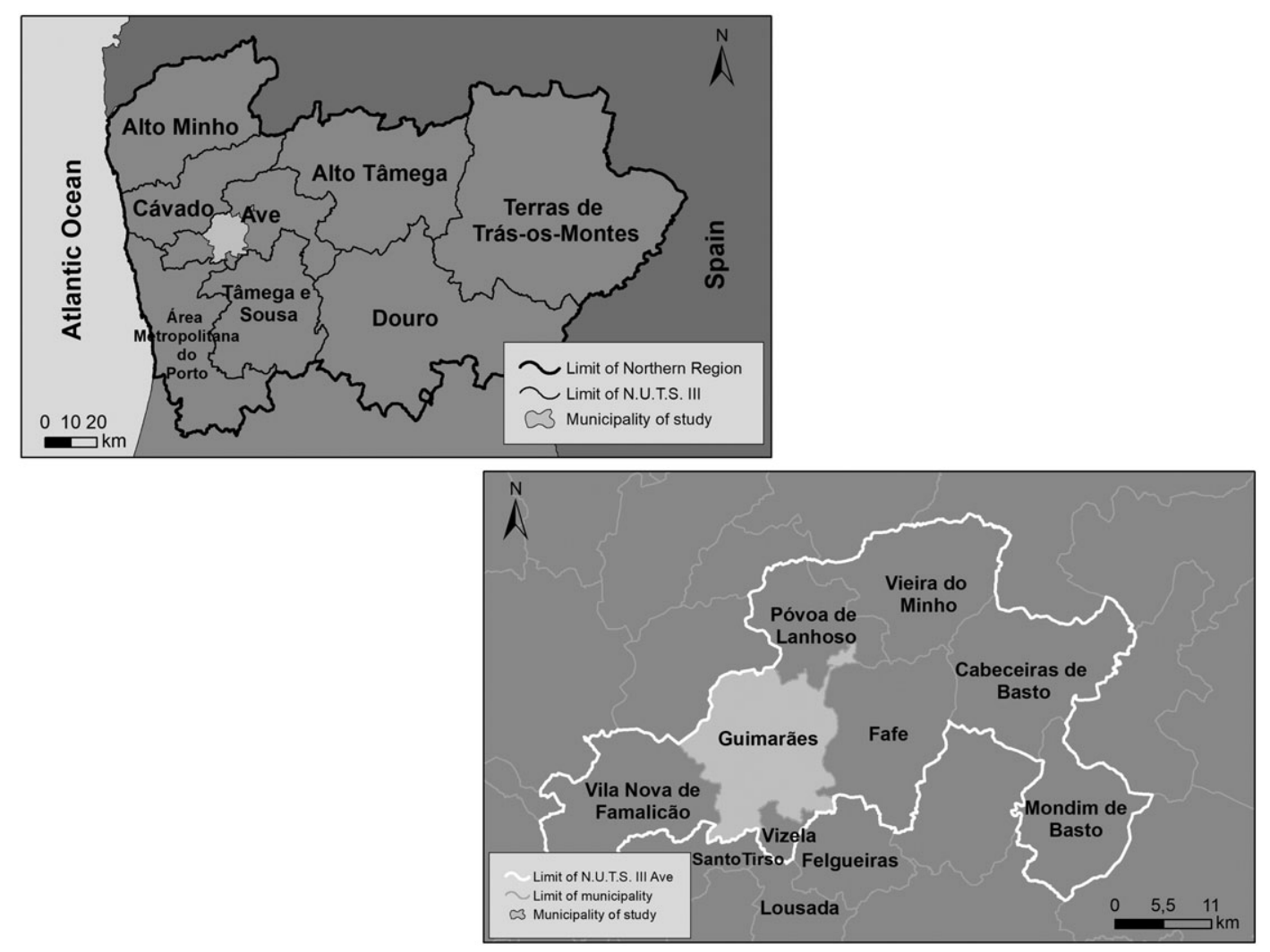

FIGURE 1 North of Portugal, NUTS III Ave and its municipalities (including Guimarães) 
(67\%) were married, and $84 \%$ were foreigners. These represent the general profile of tourists who visit cultural and heritage destinations, but only regarding a few characteristics-more women than men use to visit this kind of destinations, as well as older and with higher levels of education than tourists average are usually found (as stated by Silberberg, 1995). However, following the recent transformations in the profile of cultural tourists, Perez (2009) showed an increase of the younger segments in these kind of destinations.

The sample structure was not far from the one found in Bosque and Martín (2008), with 807 individuals visiting a destination in Spain. The major difference refers to the amount of foreigners inquired. In the case of the empirical research performed by these authors (Bosque \& Martín, 2008), the dominant origin was the domestic market (nationals), who accounted for $85.6 \%$ of the respondents. Some similarity can also be found in the structure of respondents of the survey used by Moreno et al. (2016) to approach tourists' motivation towards visiting the Valparaíso (Chile) World Heritage Site. The most notorious difference vis-à-vis the previously identified samples regards to the balance of national (52.3\%) and foreign tourists surveyed.

\section{2 | Cluster analysis}

As indicated, the main aims of this paper are to investigate the level of satisfaction tourists get from visiting Guimarães and their willingness to return to this cultural destination, or at least to recommend the visit to family and friends. Following the literature (see Antón et al., 2017; Yoon \& Uysal, 2005), we assume that this willingness keeps a relation with the perceived quality of the destination or to a few of its attributes and previous visiting experiences (Antón et al., 2017; Campo-Martínez et al., 2010; Oliver, 1999).

Additionally, we also know that different travel groups gain different levels of satisfaction from visiting a destination (see Bigné \& Andreu, 2004; Campo-Martínez et al., 2010; Castro et al., 2007; Hui et al., 2007). Keeping this in mind, as a first move in the analysis of data, a cluster analysis was performed.

A non-hierarchical clustering approach ( $k$-means), in which the individuals are iteratively moved into clusters, was adopted to minimize the variability within clusters and maximize the variability between clusters. This clustering approach was performed on three different cluster solutions ( $n=3,4,5)$. Comparing the results obtained from these solutions, the three clusters solution was selected for further analysis because it provided the greatest difference between clusters and yielded the most interpretable results. The comparison of the intra-group variability was based on the mean distances of each tourist from his or her cluster centroid (Table 1). The data indicated that Clusters 1 and 2 have the greatest level of disparity, whereas Clusters 2 and 3 show greater similarity.

An analysis of the different clusters was carried out by examining the mean score for the 18 items measuring the attributes of Guimarães (Table 2), thus revealing the tourists' agreement/disagreement regarding these items for each cluster. The results attained (Table 2 ) indicate that the contribution of all attributes was significant for defining the clusters ( $p$ value $<0.01$ ). In addition, the attributes that differentiated
TABLE 1 Intra-group variability

\begin{tabular}{llll} 
Clusters & $\mathbf{1}$ & $\mathbf{2}$ & $\mathbf{3}$ \\
\hline 1 & & 5.951 & 3.410 \\
\hline 2 & 5.951 & & 2.944 \\
\hline 3 & 3.410 & 2.944 & \\
\hline
\end{tabular}

Source: Calculations based on the authors' own survey data.

the clusters the most are as follows: "Good range of entertainment in terms of quality," "Good range of entertainment in terms of quantity," and "Quality and diversity of general shops." The attributes that differentiated the clusters the less are as follows: "Good transport services"; "Linked to the origin of the Portuguese nationality"; and "Relevant, artistic, and monumental heritage."

Following our results (Table 2), the three clusters kept can be characterized as follows:

Cluster 1-Enthusiastic: This cluster contains $30 \%$ of the sample of respondents. These respondents are the most firmly convinced of the positive attributes of Guimarães, with only one item indicating a percentage lower than $82 \%$ (good transport services, with $72.9 \%$ ). One hundred per cent agree that Guimarães is a "welcoming city"; 97.7\% agree that it has a "relevant, artistic, and monumental heritage"; and $96.9 \%$ agree that it has "cleanliness of places" and a "good rehabilitation of historical centre."

This is the more gender-balanced cluster (men-51.9\%; women$48.1 \%$ ), containing the youngest and least-educated tourists, when compared with the other clusters. This cluster has the highest percentage of Portuguese tourists. Touring, its classification as a World Heritage Site, and the city's gastronomy and wines emerged as the main motivations for visiting the city as their main destination.

Cluster 2-Unconvinced: These participants constitute the smallest group, involving $27 \%$ of the sample. In comparison with the other clusters, the Unconvinced are less certain about the attributes of Guimarães. Only a very small percentage of tourists completely agree with the statements they were confronted with. The attribute that met the highest total agreement within this group was "cleanliness of places visited." None of the statements attracted high levels of agreement within the group, with the majority choosing to respond "do not agree or disagree." This group has the highest percentage of dissatisfaction with the attributes of Guimarães, specifically the quantity and quality of entertainment and the "good dissemination of cultural events."

The demographic profile of the tourists belonging to this cluster is marked by the highest percentage of females, the lowest percentage of younger tourists, and people who are well educated (with the lowest percentage of tourists with basic education). Touring, its classification as a World Heritage site, and the architectural heritage emerged as the main motivations for visiting the city (similar to Cluster 3). Cluster 2 has the lowest percentage of visitors choosing Guimarães as the main destination and the highest percentage of those choosing Oporto instead.

Cluster 3-Satisfied: This is the largest group of respondents, comprising $43 \%$ of the sample. Like Cluster 1 , these respondents held extremely positive views about the attributes of Guimarães, but the percentage of those who completely agreed is much lower. For 
TABLE 2 Guimarães perceived attributes

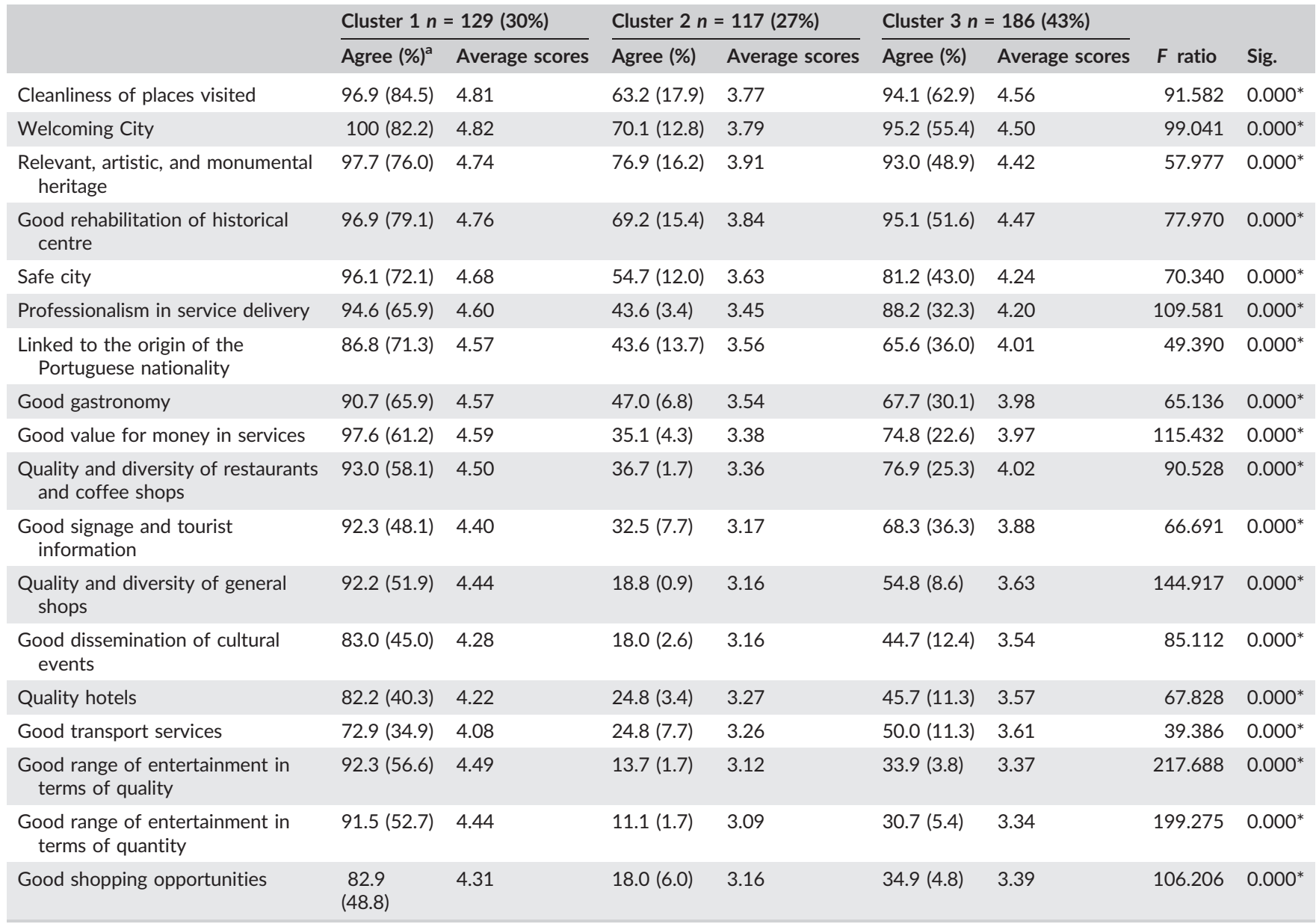

Source: Calculations based on the authors' own survey data. ${ }^{*} p<0.01$.

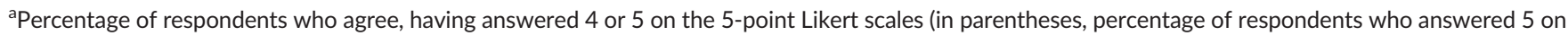
the 5-point Likert scale).

instance, although $82.2 \%$ of the $100 \%$ of tourists in Cluster 1 completely agree that Guimarães is a welcoming city, only $55.4 \%$ of the $95.2 \%$ of tourists in Cluster 2 do so. This cluster has the highest percentage of males, including people who are well educated and the lowest percentage of Portuguese tourists. The classification as a World Heritage site, touring, and the architectural heritage emerged as the main motivations for visiting the city. Oporto and Braga emerged as the main destinations chosen.

Considering $\mathrm{H} 1$, regarding the perception of the city's attributes, relying on the clusters found, we have to conclude that we are confronted with tourists endowed of different socio-demographic profiles and visit motivations.

\subsection{Intention to return model}

In order to analyse the variables that affect the likelihood of a return to the destination, a logistic regression analysis was performed. The logistic regression model gives us an equation that can be used to estimate the likelihood of an events occurrence (in this study, the intention whether or not to return to Guimarães), based on the values of variables that are considered to be explanatory. Following the review of literature (Antón et al., 2017; Campo-Martínez et al., 2010; Chen \& Chen, 2010; Chi \&
Qu, 2008; Kozak, Bigné, \& Andreu, 2005; Petrick \& Backman, 2002; Yoon $\&$ Uysal, 2005), we adopted the following variables: global quality of the destination, satisfaction, and prior experience of visiting the destination.

The tourists' return intention was measured, as in Anderson and Sullivan (1993), Chen and Tsai (2007), and Campo-Martínez et al. (2010), using a 5-point Likert scale, representing different rates of intention to revisit Guimarães. However, because the main goal of this paper was to determine whether the independent variables introduced in the model jointly contributed to the increase in the probability of the intent to return to the destination, the intent variable had to be dichotomous (expressing whether the tourist had the intent to revisit the destination or not), instead of categorical (the rate of intent to revisit Guimarães). Therefore, in order to perform a binomial logistic regression model, the categorical variable, return, was transformed into a new dichotomous variable with two possible answers: (1) certainty of returning and (0) any other situation (not returning or not being sure of it).

Satisfaction and the global image of the destination can be measured in an overall way or as the result of multidimensional interaction among a number of variables rated by the consumer (Miller, 1976, cited by Campo-Martínez et al., 2010; Cruz Ruiz, Bermúdez González, \& Tous Zamora, 2018; Kaplanidou \& Vogt, 2007; Petrick, Morais, \& Norman, 2001; Petrick \& Backman, 2002). In this study, the first approach was taken, and satisfaction and the global quality of the 
destination were measured in a one-dimensional way (following Bigné et al., 2001; Campo-Martínez et al., 2010; Chen \& Tsai, 2007; Oh, 1999; Petrick, 2004; Soderlund, 1998; and Zins, 2001).

Previous tourists' experience with the destination is measured in the questionnaire as the number of times that the tourist has visited it in the past, including the current one (such as Campo-Martínez et al., 2010; Kozak et al., 2005; and Lam \& Hsu, 2006).

Before performing the logistic regression, we calculated a means test in order to identify whether there were significant differences in the obtained satisfaction levels, perceived image, previous experience with the destination, and recommendations made, depending on the cluster. The results of that test are shown in Table 3. As can be inferred from previous analyses, significant differences were found, depending on the different clusters.

As for the explanatory variables included in the study, it can be observed that the highest mean values for all variables correspond to Cluster 1, while the lowest correspond to Cluster 2. Cluster 1 displays the highest mean value regarding the recommendation of Guimarães to family and friends (4.53) and is the group that captures the higher amount of previous visits to the destination.

Regarding the logit model, the model's parameters are estimated using the maximum likelihood method. Cox and Snell and Nagelkerke's pseudo $R^{2}$ statistics and the -2 log likelihood were used to measure the model's goodness of fit and are presented in Table 4 for the total tourist sample.

The values of the Cox and Snell and Nagelkerke's pseudo $R^{2}$ statistics are reasonable- 0.153 and 0.206 , respectively-although they should be considered with caution, because none of the statistics explains variance in the same way as the $R^{2}$ coefficient of a linear regression model.

Table 5 contains the results of the analysis. Within the whole set of tourists under analysis, the estimated parameters show that perceived global quality, prior experience on the destination and satisfaction level play significant roles in motivating tourists to revisit the city. The first two variables have a significant influence on revisiting intentions at a confidence level of $99 \%$, and the latter of 95 .
TABLE 4 Model's overall goodness of fit to the data (total sample)

\begin{tabular}{|lc|}
\hline Cox and Snell $R^{2}$ & Total sample \\
\hline Nagelkerke $R^{2}$ & 0.153 \\
\hline-2 times log likehood & 0.206 \\
\hline
\end{tabular}

TABLE 5 Relationship between explanatory variables and the intention to return to the destination: Total sample

\begin{tabular}{|lc|} 
& Estimated parameters \\
\hline Constant & $-7.408^{*}$ \\
\hline Global quality of the destination & $0.947^{*}$ \\
\hline Satisfaction felt with the holidays in Guimarães & $0.539^{* *}$ \\
\hline Number of visits to Guimarães & $0.415^{*}$
\end{tabular}

${ }^{*} p<0.01 .^{* *} p<0.05$.

With these findings, we can accept $\mathrm{H} 2-\mathrm{H} 4$, when using the all sample. In other words, it can be said that the likelihood of a return visit to the destination is positively dependent on tourists' satisfaction with or good impression of the visit made and on the learning effect (i.e., the more familiar they are with the destination, the more likely they are to return). However, differences in the coefficients show that, although the global quality of the destination contributes the most to the return intention, satisfaction with the holiday contributes the least.

In continuation, an analysis was conducted for each of the previously defined tourist clusters. As can be inferred from an analysis of Table 6, the values of the Cox and Snell and Nagelkerke's pseudo $R^{2}$ statistics are higher for Cluster 1 than for the whole sample, being these statistical values reasonable. Clusters 2 and 3 achieve lower values, showing lower consistency of the model.

Table 7 shows the results of the estimated parameters for the different cluster samples. The results indicate that the influence of satisfaction, global quality, and experience variables on the intention to return differ depending on the travelling group composition.

TABLE 3 Satisfaction and recommendation

\begin{tabular}{|c|c|c|c|c|c|c|c|c|}
\hline & \multicolumn{2}{|c|}{ Cluster 1 n = $129(30 \%)$} & \multicolumn{2}{|c|}{ Cluster 2 n = $117(27 \%)$} & \multicolumn{2}{|c|}{ Cluster $3 n=186(43 \%)$} & \multirow[b]{2}{*}{$F$ ratio } & \multirow[b]{2}{*}{ Sig. } \\
\hline & Agree $(\%)^{a}$ & Average scores & Agree $(\%)^{a}$ & Average scores & Agree $(\%)^{a}$ & Average scores $^{b}$ & & \\
\hline Global quality of the destination ${ }^{\mathrm{b}}$ & $98.5(66.7)$ & 4.65 & $88.0(5.1)$ & 3.93 & $94.1(36.0)$ & 4.30 & 59.836 & $0.000^{*}$ \\
\hline Will return ${ }^{d}$ & $66.7(41.1)$ & 3.98 & $29.0(12.8)$ & 3.03 & $30.6(14.5)$ & 3.16 & 30.346 & $0.000^{*}$ \\
\hline Recommendation to family and friends ${ }^{\mathrm{e}}$ & $89.1(68.2)$ & 4.53 & $81.2(39.3)$ & 4.15 & $86.6(53.8)$ & 4.36 & 6.861 & $0.001^{*}$ \\
\hline
\end{tabular}

Source: Calculations based on authors own survey data.

aPercentage of respondents who agree, having answered 4 or 5 on the 5 -point Likert scales (in parentheses, percentage of respondents who answered 5 on the 5-point Likert scale).

${ }^{\mathrm{b}}$ Scale ranges from 1 (bad) to 5 (excellent).

'Scale ranges from 1 (not at all satisfied) to 5 (very satisfied).

${ }^{\mathrm{d}}$ Scale ranges from 1 (0\% hypothesis) to 5 (100\% hypothesis).

${ }^{\text {e}}$ Scale ranges from 1 (do not recommend) to 5 (strongly recommend).

${ }^{*} p<0.01$. 
TABLE 6 Each model's overall goodness of fit with the data

\begin{tabular}{lrrr|} 
& Cluster 1 & Cluster 2 & Cluster 3 \\
\hline Cox and Snell $R^{2}$ & 0.178 & 0.094 & 0.073 \\
\hline Nagelkerke $R^{2}$ & 0.247 & 0.134 & 0.102 \\
\hline -2 times log likelihood & 139.952 & 129.512 & 215.238 \\
\hline
\end{tabular}

TABLE 7 Relationship between explanatory variables and the intention to revisit the destination: Subsamples

\begin{tabular}{lrcc}
\hline Estimated parameters & Cluster 1 & Cluster 2 & Cluster 3 \\
\hline Constant & $-10.418^{*}$ & $-7.002^{*}$ & $-5.409^{*}$ \\
$\begin{array}{l}\text { Global quality of the } \\
\text { destination }\end{array}$ & 0.648 & $1.895^{* *}$ & $0.753^{* * *}$ \\
$\begin{array}{c}\text { Satisfaction with the holidays } \\
\text { in Guimarães }\end{array}$ & $1.615^{*}$ & -0.500 & 0.187 \\
$\begin{array}{c}\text { Number of visits to } \\
\text { Guimarães }\end{array}$ & 0.368 & 0.413 & 0.327 \\
\hline
\end{tabular}

${ }^{*} p<0.01{ }^{* *} p<0.05 .{ }^{* * *} p<0.1$.

More specifically, the estimated parameter relating to satisfaction is significant for Cluster 1 visitors at a confidence level of $99 \%$, whereas the parameter for the global quality variable is significant at a $95 \%$ confidence level for Cluster 2 and at a $90 \%$ confidence level for Cluster 3. Interestingly, the number of visits is not significant for any of the clusters identified.

With these results, and although for the total tourists sample $\mathrm{H} 2$ $\mathrm{H} 4$ can be accepted, we have to conclude that the composition of each cluster does make a difference. When taking Cluster 1 , satisfaction influences positively the desire to return, that is, $\mathrm{H} 3$ can be accept. For Clusters 2 and 3, the global quality of the destination shows making these tourists to want revisit the destination, that is, $\mathrm{H} 2$ can be accept, in both cases. $\mathrm{H} 4$ cannot be accepted for any of the clusters. Table 8 summarizes the factors that contribute the most and the least for a further visit to the destination, following the hypotheses tested.

Looking at the empirical results attained, one has to agree that satisfaction towards a destination results from the overall experience lived, as claimed by Bosque and Martín (2008), Chen and Chen (2010), Petrick and Backman (2002), and Yoon and Uysal (2005). In this regard, it is worth to remember that the perceived global quality of a destination or image of it which was kept is surely the key factor behind enjoying or not visiting a site (Antón et al., 2017; Bigné et al., 2005; Bosque \& Martín, 2008; Campo-Martínez et al., 2010; Chiu et al., 2016), even if that can be expressed differently according to different groups of visitors, as underlined by Campo-Martínez et al. (2010). Enjoying visiting a destination and returning to it is another issue (Nam et al., 2011).

TABLE 8 Influences on revisiting intentions by subsamples

\begin{tabular}{llll}
$\begin{array}{l}\text { Sample } \\
\text { used }\end{array}$ & $\begin{array}{l}\text { Most } \\
\text { influential }\end{array}$ & $\begin{array}{l}\text { Least } \\
\text { influential }\end{array}$ & $\begin{array}{l}\text { Acceptance of } \\
\text { hypotheses }\end{array}$ \\
\hline Total & Global quality & Number of visits & $\mathrm{H} 2-\mathrm{H} 4$ \\
\hline Cluster 1 & Satisfaction & Not significant & $\mathrm{H} 3$ \\
Cluster 2 & Global quality & Not significant & $\mathrm{H} 2$ \\
Cluster 3 & Global quality & Not significant & $\mathrm{H} 2$ \\
\hline
\end{tabular}

In this respect, Bigné et al. (2001) and Lee et al. (2007) claim that a relationship between satisfaction and return intention was far from being confirmed. That is, loyalty and repeat visit intention are not the same (Nam et al., 2011). Certainly, enjoying a visit and showing loyalty can be expressed other ways, namely, recommending the destination to family and friends (behaviour loyalty).

As mentioned, the composition of the travelling group does seem to play a role in the level of satisfaction attained. We found that the intention to return to Guimarães related mostly with satisfaction among Cluster 1 visitors, whereas the most relevant parameter for Clusters 2 and 3 was the global quality kept. These findings support the aforementioned claim, following the findings of Bigné and Andreu (2004), Campo-Martínez et al. (2010), Castro et al. (2007), Hui et al. (2007), and Lee et al. (2007).

The amount of previous visits also did not allow expression in statistically significant new return intentions for any of the clusters identified but presented statistical significance for the whole sample. This considered, one must conclude that having a good tourist experience at a destination does enhance the probability that one will return to it. Once the positive experience is confirmed, the intent of returning can be renewed again (Bosque \& Martín, 2008). However, that can be felt differently by each group of visitors. If each of those groups has distinct motivations and enjoys the experience differently, the results we get should not be considered surprising. This result follows also the claims of Lee et al. (2007) as well as those of Campo-Martínez et al. (2010).

\section{5 | CONCLUSIONS AND RECOMMENDATIONS}

The main aim of this paper was to inquire on the Guimarães visitors' return intention and relating it to the satisfaction attained at the destination, the global quality perception or image kept, and previous experiences acquired while visiting it. Even so, one must admit that different segments of tourists, according to their motivations and sociocultural profiles, can express distinct levels of satisfaction towards the same destination, even while being part of the same tour. This justifies examination of the influential factors of those different groups.

Cluster analysis was used in our investigation because it can provide the basis for a focussed approach to the planning and management of the tourism activity in emerging destinations, such as Guimarães.

We succeeded to identify three clusters: the Enthusiastic (30\% of the sample of respondents), the Unconvinced ( $27 \%$ of the sample), and the Satisfied ( $43 \%$ of the sample). We concluded that the level of satisfaction tourists gained from visiting Guimarães, a city remarkable for its cultural heritage, was quite high, even if they do not show a homogeneous evaluation.

For capturing the variables that affect the likelihood of a return visit to the destination, we performed a logistic regression analysis, considering the whole sample and the clusters identified. From there, looking first at the whole set, perceived global image, prior experience at the destination, and satisfaction level are shown to play significant 
roles in motivating tourists to return to it. However, differences in the coefficients show that, although the global quality of the destination contributed the most to the return intention, the satisfaction felt with the holidays contributes the least.

In terms of the visitors' clusters, the results of the logit model indicate that the influence of satisfaction, global quality, and experience variables on the intention to return differ, depending on the travelling group composition. In this regard, the Enthusiastic indicates that the parameter relating to satisfaction was significant at a confidence level of $99 \%$, whereas for the Unconvinced and the Satisfied, the parameter which shown to play a major role in the intent to return was the global quality variable, at a 95\% confidence level. In all cases, the amount of visits is not shown as significant for explaining the returns declared in any of the clusters identified.

This empirical evidence should, of course, be considered when looking the planning, managing, and promotion of the destination. This raises two sorts of problems: on the one hand, there is occasion to inquire if the destination positions itself mainly as a heritage destination, based on its acquired attributes and products provided; and second, one must consider if the destination should envisage attracting the visitors we classified as Unconvinced. In this case, the issue is not in leading them to repeat the visit but simply capturing this segment of tourists who are not heritage motivated.

Perhaps the experience that the destination proposes is too passive for these visitors. In fact, the sites that can be visited only suggest a passive interaction with visitors. Also, the relevant patrimony of the Portuguese history cannot be enough to ensure the satisfaction of the visitors. Authorities must think in a more interactive and creative way and make the heritage "come alive." To do so, they must think in terms of a more creative tourism segment that could complement the more traditional way of experiencing heritage. This new kind of tourism can increase the co-creation of experiences and is linked to the latest tendencies that are linked to both significant and authentic experiences and to active involvement with culture and contact with real people (Richards \& Wilson, 2008).

This said, we are not suggesting that Guimarães does not need to identify its attributes and promote them better in order to position itself in the target tourism market and prevent major misunderstandings on the kind of destination we are examining. As individuals express their satisfaction towards a destination based on a prior image, marketing promoters should, in the advertising of the destination, not create unrealistic expectations for the potential visitors, thus preventing them from feeling frustrated with the experience and emotions experienced there.

The empirical results attained bring additional support to the idea that enjoying a visit and returning to it are not the same. Loyalty can be expressed in other ways, such as recommending the destination to family and friends. This is an issue that we have not addressed directly in this paper, so the opportunity exists for exploring it in future research.

Even when dealing with the Guimarães destination based on the results of survey, one should be aware that the sample used is a convenience one. Anyway, one must underline that it has the advantage of being easy to compare with the ones which have been previously conducted.
The major limitation of our research was having a higher amount of foreigners than domestic tourists, knowing that Guimarães is still receiving more domestic than foreigner ones, hereby conditioning to generalize or to extrapolate results obtained. Nevertheless, the methodology used was the suitable one, as the tourism office was the more appropriate place to apply the survey due to logistic and budget reasons. In fact, besides the budget reasons mentioned, this kind of approach works better than the one of applying the surveys on the streets or on the hotels, where tourists tend to not answering. Using a tourism office allows the tourists to have access to information on the destination, and we can expect them to show a more positive reaction towards such a questionnaire. Assuming this receptivity relates to the fact that they get in contact with the office tourism service providers, which, at the same time, will provide them information on the city and they are looking for and can help them in the process of filling in the questionnaire. For the tourism office is also an easy way of getting information on their visitors, which can be quite valuable in terms of better managing and planning the city tourist supply.

In further research, the team will take into account the results obtained and will focus on investigating what can be done to achieve a more complete and holistic offer, trying to take better tourism profit from the rich intangible heritage that characterizes the city of Guimarães.

\section{ACKNOWLEDGEMENTS}

This work has the financial support of the UNIAG-Applied Management Research Unit, R\&D unit funded by the FCT-Portuguese Foundation for the Development of Science and Technology, Ministry of Science, Technology and Higher Education, through national funds under the project UID/GES/04752/2016; and Lab2PT-Laboratory of Landscapes, Heritage and Territory-AUR/04509 and of FCTMEC through national funds and when applicable of the ERDF co-financing, under the new partnership agreement PT2020.

\section{ORCID}

Laurentina Vareiro (D) https://orcid.org/0000-0001-8945-1593

José Cadima Ribeiro (i) https://orcid.org/0000-0002-4434-0766

Paula Cristina Remoaldo (D) https://orcid.org/0000-0002-9445-5465

\section{REFERENCES}

Anderson, E. W., \& Sullivan, M. W. (1993). The antecedents and consequences of customer satisfaction for firms. Marketing Science, 12(2), 125-143. https://doi.org/10.1287/mksc.12.2.125

Antón, C., Camarero, C., \& Laguna-García, M. (2017). Towards a new approach of destination royalty drivers: Satisfaction, visit intensity and tourist motivation. Current Issues in Tourism, 20(3), 238-260. https://doi.org/10.1080/13683500.2014.936834

Baker, D. A., \& Crompton, J. L. (2000). Quality, satisfaction and behavioural intentions. Annals of Tourism Research, 27(3), 785-804. https://doi.org/ 10.1016/S0160-7383(99)00108-5

Baloglu, S., \& McCleary, K. W. (1999). A model of destination image formation. Annals of Tourism Research, 26(4), 868-897. https://doi.org/ 10.1016/S0160-7383(99)00030-4

Bigné, E., Andreu, L., \& Gnoth, J. (2005). The theme park experience: An analysis of pleasure, arousal and satisfaction. Tourism Management, 26(6), 833-844. https://doi.org/10.1016/j.tourman.2004.05.006 
Bigné, E., Sanchez, M. I., \& Sanchez, J. (2001). Tourist image, evaluation variables and after purchase behaviour: Interrelationship. Tourism Management, 22(6), 607-616. https://doi.org/10.1016/S02615177(01)00035-8

Bigné, J. E., \& Andreu, L. (2004). Emotions in segmentation: An empirical study. Annals of Tourism Research, 31(3), 682-926. https://doi.org/ 10.1016/j.annals.2003.12.018

Bosque, I., \& Martín, H. (2008). Tourist satisfaction: A cognitive-affective model. Annals of Tourism Research, 35(2), 551-573. https://doi.org/ 10.1016/j.annals.2008.02.006

Campo-Martínez, S., Garau-Vadell, J., \& Martínez-Ruiz, M. (2010). Factors influencing repeat visits to a destination: The influence of group composition. Tourism Management, 31(6), 662-870.

Carvalho, P., Salazar, A. M., \& Ramos, P. (2015). Modelo conceptual integrativo de Destination Branding: Teste empírico no Porto e Norte de Portugal. PASOS - Journal of Tourism and Cultural Heritage, 13(4), 865-874.

Castro, C. B., Armario, E. M., \& Ruiz, D. M. (2007). The influence of market heterogeneity on the relationship between a destination's image and tourists' future behaviour. Tourism Management, 28, 175-187. https://doi.org/10.1016/j.tourman.2005.11.013

Chen, C., \& Chen, F. (2010). Experience quality, perceived value, satisfaction and behavioural intentions for heritage tourists. Tourism Management, 31(1), 29-35. https://doi.org/10.1016/j. tourman.2009.02.008

Chen, C., \& Tsai, D. (2007). How destination image and evaluative factors affect behavioural intentions? Tourism Management, 28(4), 1115-1122. https://doi.org/10.1016/j.tourman.2006.07.007

Chen, C. M., Lee, H. T., Chen, S. H., \& Huang, T. H. (2011). Tourist behavioural intentions in relation to service quality and customer satisfaction in Kinmen National Park, Taiwan. International Journal of Tourism Research, 13, 416-432. https://doi.org/10.1002/jtr.810

Chi, C. G.-Q., \& Qu, H. (2008). Examining the structural relationship of destination image, tourist satisfaction and destination loyalty: An integrated approach. Tourism Management, 29(4), 624-636. https:// doi.org/10.1016/j.tourman.2007.06.007

Chiu, W., Zeng, S., \& Cheng, P. (2016). The influence of destination image and tourist satisfaction on tourist loyalty: A case study of Chinese tourists in Korea. International Journal of Culture, Tourism and Hospitality Research, 10(2), 223-234. https://doi.org/10.1108/IJCTHR-07-20150080

Correia, A., Kozak, M., \& Ferradeira, J. (2013). From tourist motivations to tourist satisfaction. International Journal of Culture, Tourism and Hospitality Research, 7(4), 411-424. https://doi.org/10.1108/IJCTHR-052012-0022

Crompton, J. L. (1979). Motivations for pleasure vacations. Annals of Tourism Research, 6(4), 408-424. https://doi.org/10.1016/01607383(79)90004-5

Cronin, J. J., Brady, M. K., \& Hult, T. M. (2000). Assessing the effects of quality, value, and customer satisfaction on consumer behavioral intentions in service environments. Journal of Retailing, 76(2), 193-218. https://doi.org/10.1016/S0022-4359(00)00028-2

Cruz Ruiz, E., Bermúdez González, G., \& Tous Zamora, D. (2018). Destination image, satisfaction and destination loyalty in cruise tourism: The case of Malaga (Spain). Tourism and Management Studies, 14(1), 58-68. https://doi.org/10.18089/tms.2018.14105

Deng, J., \& Pierskalla, C. (2011). Impact of past experience on perceived value, overall satisfaction, and destination loyalty: A comparison between visitor and resident attendees of a festival. Event Management, 15(2), 163-177. https://doi.org/10.3727/ 152599511 X13082349958235

Gandhi-Arora, R., \& Shaw, R. N. (2002). Visitor loyalty in sport tourism: An empirical investigation. Current Issues in Tourism, 5(1), 45-53. https:// doi.org/10.1080/13683500208667907

Grönroos, C. (2004). Marketing: Gerenciamento e serviços. Rio de Janeiro: Elsevier.
Hui, T. K., Wan, D., \& Ho, A. (2007). Tourists' satisfaction recommendation and revisiting Singapore. Tourism Management, 28, 965-975. https:// doi.org/10.1016/j.tourman.2006.08.008

I.N.E (2016). Anuário Estatístico da Região Norte 2015. Lisboa: Instituto Nacional de Estatística.

Kaplanidou, K., \& Vogt, C. (2007). The interrelationship between sport event and destination image and sport tourists' behaviours. Journal of Sport and Tourism, 12(3-4), 183-206. https://doi.org/10.1080/ 14775080701736932

Kozak, M., Bigné, E., \& Andreu, L. (2005). Satisfaction and destination loyalty: A comparison between non-repeat and repeat tourists. Current Issues in Tourism, 5(1), 43-59.

Lam, T., \& Hsu, C. (2006). Predicting behavioral intention of choosing a travel destination. Tourism Management, 27(4), 589-599. https://doi. org/10.1016/j.tourman.2005.02.003

Lee, I. S., Lee, T. J., \& Arcodia, C. (2014). The effect of community attachment on cultural festival visitors' satisfaction and future intentions. Current Issues in Tourism, 17(9), 800-812. https://doi.org/10.1080/ 13683500.2013.770450

Lee, Y., Petrick, J. F., \& Crompton, J. (2007). The roles of quality and intermediary constructs in determining festival attendees' behaviorial intention. Journal of Travel Research, 45(4), 402-412.

Martin, H., \& Bosque, I. (2008). Exploring the cognitive-affective nature of destination image and the role of psychological factors in its formation. Tourism Management, 29(2), 263-277. https://doi.org/10.1016/j. tourman.2007.03.012

Moore, S. A., Rodger, K., \& Taplin, R. (2015). Moving beyond visitor satisfaction to loyalty in nature-based tourism: A review and research agenda. Current Issues in Tourism, 18(7), 667-682. https://doi.org/ 10.1080/13683500.2013.790346

Moreno, R., Gálvez, J., Ortuya, F., \& López-Guzmán, T. (2016). Factores de interés de un destino Patrimonio de la Humanidad: El caso de Valparaíso-Chile. Estudios Y Perspectivas en Turismo, 25(3), 360-374.

Nam, J., Ekinci, Y., \& Whayatt, J. (2011). Brand equity, brand loyalty and consumer satisfaction. Annals of Tourism Research, 38(3), 1009-1030. https://doi.org/10.1016/j.annals.2011.01.015

Oh, H. (1999). Service quality, customer satisfaction, and customer value: A holistic perspective. International Journal of Hospitality Management, 18(1), 67-82. https://doi.org/10.1016/S0278-4319(98)00047-4

Oliver, R. (1993). Cognitive, affective and attribute bases of the satisfaction response. Journal of Consumer Research, 20(3), 418-430. https:// doi.org/10.1086/209358

Oliver, R. (1997). Satisfaction: A behavioral perspective on the consumer. New York, NY: McGraw-Hill.

Oliver, R. (1999). Whence consumer loyalty? Journal of Marketing, 63(special issue), 33-44. https://doi.org/10.1177/00222429990634s105

Perez, X. (2009). Turismo Cultural. Uma visão antropológica. Colección PASOS edita, 2, Tenerife.

Petrick, J. (2004). First timers' and repeaters' perceived value. Journal of Travel Research, 43(1), 29-38. https://doi.org/10.1177/ 0047287504265509

Petrick, J. P., \& Backman, S. J. (2002). An examination of the determinants of golf travelers' satisfaction. Journal of Travel Research, 40(3), 252-258. https://doi.org/10.1177/004728750204000303

Petrick, J. P., Morais, D., \& Norman, W. (2001). An examination of the determinants of entertainment vacationers' intentions to revisit. Journal of Travel Research, 40(1), 41-48. https://doi.org/10.1177/ 004728750104000106

Poria, Y., Reichel, A., \& Cohen, R. (2011). World Heritage Site-Is It an Effective Brand Name?: A Case Study of a Religious Heritage Site. Journal of Travel Research, 50(5), 482-495.

Prayag, G., Hosany, S., \& Odeh, K. (2013). The role of tourists' emotional experiences and satisfaction in understanding behavioral intentions. Journal of Destination Marketing and Management, 2(2), 118-127. https://doi.org/10.1016/j.jdmm.2013.05.001 
Remoaldo, P. C., Ribeiro, J. C., Vareiro, L., \& Santos, J. F. (2014). Tourists perceptions of world heritage destinations: The case of Guimarães (Portugal). Tourism and Hospitality Research, 14(4), 206-218. https:// doi.org/10.1177/1467358414541457

Richards, G., \& Wilson, A. (2008). From cultural tourism to creative tourismPart 1: The changing context of cultural tourism. Arnham: ATLAS.

Silberberg, T. (1995). Cultural tourism and business opportunities for museums and heritage sites. Tourism Management, 16(2), 361-365. https://doi.org/10.1016/0261-5177(95)00039-Q

Soderlund, M. (1998). Customer satisfaction and its consequences on customer behavior revisited. The impact of different levels of satisfaction on word-of-mouth, feedback to the supplier and loyalty. International Journal of Service Industry Management, 9(2), 169-188. https://doi. org/10.1108/09564239810210532

Vanhove, N. (2004). The economics of tourism destinations. London: Butterworth Heinemann.

Wongpan, S., \& Khamwon, A. (2016). Destination brand experience, satisfaction, and behavioral intention: Evidence from Mice Khon Kaen. Conference of the International Journal of Arts \& Sciences, CD-ROM. ISSN: 1943-6114, 09(01), 281-288. (2016)
Wu, M., \& Liu, C. (2017). The influences of motivations, past experiences, destination image, event image, satisfaction, and intentions on participation in Taiwan road running events. The Journal of Human Resource and Adult Learning, 13(1), 26-38.

Yoon, Y., \& Uysal, M. (2005). An examination of the effects of motivation and satisfaction on destination loyalty: A structural model. Tourism Management, 26(1), 45-56. https://doi.org/10.1016/j. tourman.2003.08.016

Zhang, H., Fu, X., Cai, L., \& Lu, L. (2014). Destination image and tourist loyalty: A meta-analysis. Tourism Management, 40, 213-223. https:// doi.org/10.1016/j.tourman.2013.06.006

Zins, A. (2001). Relative attitudes and commitment in customer loyalty models. International Journal of Service Industries Management, 12(3), 269-294. https://doi.org/10.1108/EUM0000000005521

How to cite this article: Vareiro L, Ribeiro JC, Remoaldo PC. What influences a tourist to return to a cultural destination? Int J Tourism Res. 2019;21:280-290. https://doi.org/ 10.1002/jtr.2260 